\title{
Avaliação clínica e eletromiográfica da mastigação nos diferentes padrões de crescimento facial
}

\author{
Clinical and electromyographic evaluation of mastication \\ within different facial growth patterns
}

Luciele da Silva Prates ${ }^{(1)}$

Marjana Gois ${ }^{(1)}$

Luana Cristina Berwig( ${ }^{(2)}$

Ana Paula Blanco-Dutra(3)

Angela Ruviaro Busanello-Stella(3)

Ana Maria Toniolo da Silva(1)

\footnotetext{
(1) Departamento de Fonoaudiologia da Universidade Federal de Santa Maria UFSM - Santa Maria (RS), Brasil.

(2) Universidade Federal de Santa Maria UFSM - Santa Maria (RS), Brasil.

(3) Departamento de Fonoaudiologia da Universidade Federal de Santa Catarina - UFSC - Florianópolis (SC), Brasil.

Study conducted at the Speech-Language Pathology Course, Federal University of Santa Maria (RS), Brazil.

Conflict of interest: non-existent
}

Received on: May 12, 2015

Accepted on: July 05, 2015

Mailing address:

Luciele da Silva Prates

Avenida Roraima, 1000, Prédio 26, 1433.

Camobi, Km 9

Santa Maria - RS - Brasil

CEP: $97105-900$

E-mail: lucieleprates@outlook.com

\section{ABSTRACT}

Purpose: to analyze masticatory function within different facial types through clinical and electromyographic evaluation of masseter and anterior temporalis muscles.

Methods: sixty-five children aged six to 12 years old, males and females, who met the study criteria, were selected. The clinical evaluation of mastication was performed based on the MBGR protocol, as well as the electromiography of masseter and anterior temporalis muscles, on the right and left side in directed continued mastication. The data were analyzed considering the significance level of $5 \%$.

Results: in the clinical evaluation of mastication, no significant differences between the three facial types studied were observed, except for a tendency to significance in unexpected muscle contractions, with the highest occurrence observed in dolichofacials $(66.67 \%)$, followed by mesofacials $(46.67 \%)$ e brachyfacials (26.83\%). Through electromyographic evaluation, no significant differences between the three groups studied were observed. Comparing the muscles within each facial type, a higher electrical activity of the right masseter muscle over the right temporal, and a higher electrical activity of the left temporal muscle over the right temporal muscle $(p=0.049)$ was verified.

Conclusion: the results of clinical and electromyographic evaluations of mastication did not differ within the facial types, suggesting that the pattern of facial growth itself is not a determinant in the modifications of the masticatory function and these modifications might be related to other variations not taken into account in this study.

Keywords: Face; Cephalometry; Stomatognathic System; Mastication; Electromyography

\section{RESUMO}

Objetivo: analisar a função mastigatória nos diferentes padrões faciais de crescimento por meio da avaliação clínica e eletromiográfica dos músculos masseteres e temporais anteriores.

Métodos: foram selecionadas 65 crianças entre seis e 12 anos de idade, de ambos os sexos, que se adequaram aos critérios do estudo. Foi realizada avaliação clínica da mastigação tendo por base 0 protocolo MBGR e a avaliação eletromiográfica dos músculos masseteres e temporais anteriores, mediante mastigação contínua direcionada. Os dados foram analisados considerando nível de significância de $5 \%$.

Resultados: na avaliação clínica da mastigação, não foi observada diferença significante entre os três padrões faciais estudados, apenas tendência à significância para as contrações musculares não esperadas, sendo observada maior ocorrência nos dolicofaciais (66,67\%), seguido dos mesofaciais $(46,67 \%)$ e braquifaciais (26,83\%). Na avaliação eletromiográfica da mastigação, não foi observada diferença significante entre os três grupos estudados. Ao comparar os músculos para cada padrão facial, verificou-se nas crianças braquifaciais maior atividade elétrica do músculo masseter direito em relação ao temporal direito e maior atividade elétrica do músculo temporal esquerdo em relação ao músculo temporal direito $(p=0,049)$.

Conclusão: os resultados das avaliações clínica e eletromiográfica da mastigação não se diferiram nos padrões faciais, sugerindo que o padrão por si só não é determinante nas modificações da função mastigatória e que estas podem estar relacionadas a outras variáveis não consideradas neste estudo.

Descritores: Face; Cefalometria; Sistema Estomatognático; Mastigação; Eletromiografia 


\section{INTRODUCTION}

Facial patterns are closely linked to stomatognathic functions of each individual, such as speech, chewing, breathing and swallowing. For the efficient performance of these functions, it is necessary craniofacial structures to be in harmony'.

Characteristics that compose the craniofacial skeleton also constitute the type of face through the relationship between vertical and horizontal growth and variation of the facial type. A frequently described classification in literature sorts the face in three different facial patterns: brachyfacial, in which there is a tendency towards horizontal growth; mesofacial, prone to balanced growth of the facial thirds; and dolichofacial, with a tendency to vertical growth ${ }^{2,3}$.

Some studies ${ }^{2,4,5}$ indicate that the main clinical characteristics of brachyfacial are the higher horizontal growth; reduction of the lower third; thicker and powerful mandibular elevator muscles; ease of labial closure; tongue position supported all over the palate; greater potential for overbeat and bruxism; and wider nasal-pharyngeal functioning spaces, favoring nasal breathing. The mesofacial, on the other hand, presents balanced growth of the facial thirds; appropriate distribution of functioning space and accommodation of structures of soft tissue; and absence of adaptations of orofacial functions. The dolichofacial present mainly vertical growth; increase in the lower third; difficulty of tongue support on hard palate; difficulty with labial closure; stretched and less powerful mandibular elevator muscles; narrow nasal-pharyngeal functioning spaces, favoring oral breathing.

Mastication is a complex physiological function that depends on the development of the craniofacial complex, on the dental occlusion and on the central nervous system. Moreover, it is considered a functional unit, where teeth, jaw, temporomandibular joints, jaw muscles, lips and tongue and vascular and nervous systems of these tissues are involved ${ }^{6}$.

For an effective chewing, the activities of the masticatory, buccinator and suprahyoid muscles must be synchronized ${ }^{7}$. Besides, it must be composed by bilateral alternating movements, with the occluded lips and mandibular rotation. These characteristics enable the distribution of the masticatory strength of these structures, alternating periods of work and rest for muscles and joints, leading to muscle and functional balance ${ }^{8}$.

Due to the importance of this function, the evaluation thereof has been showing an improvement in clinical practice. This appears as a result of new features that allow complementation of qualitative with quantitative data, as the electromyographic evaluation and orofacial myofunctional evaluation based on MBGR protocol.

In this context, surface electromyography (SEMG) is an important tool for understanding the muscle behavior of the main functions of the stomatognathic system. It is also considered an objective and quantitative method, enabling the easier obtainment of the parameters for the diagnosis and contributing to the therapeutic process 9 .

The orofacial myofunctional evaluation (MBGR) furthers our understanding of the anatomical and functional conditions of the stomatognathic system, contributing to the diagnostic process and therapeutic reasoning. It is a subjective method containing some objective parameters (quantitative) that require subjective analysis by the evaluator ${ }^{10}$.

As aforementioned, this study aims to analyze the chewing function in different facial growth patterns through clinical and electromyographic evaluation of the masseter and anterior temporal muscles, so that information of masticatory function in different types of face may be provided.

\section{METHODS}

This study presented quantitative and transversal character and was linked to a major project conducted in the Orofacial Motricity Laboratory of the SpeechLanguage Pathology Course at Federal University of Santa Maria (UFSM). It was approved by the Research Ethics Committee (REC) of that institution (no. CAAE 08105512.0.0000.5346).

\section{Subjects}

The study population consisted of children from public schools located in a country town of the State of Rio Grande do Sul (RS) and from the Clinical School of the Speech-Language Pathology Course of UFSM. All subjects composing the sample agreed to participate and had parental consent obtained by the signature of the written informed consent form (WICF).

In order to be selected, children of both genders should be aged between 6-12 years, present erupted first permanent molars and be classified as eutrophic according to the clinical classification of body mass index (BMI).

Exclusion criteria included history of speech therapy and/or orthodontic treatment; two or more dental flaws, 
as long as in even tooth positions; signs indicating pathological bruxism diagnosed by dental evaluation; syndromes or craniofacial malformations; as well as incidence of neurological damage or any sign suggesting it. To check the suitability of the subjects concerning the study criteria, anamnesis and dental evaluation were performed, as well as the calculus of the BMI.

The interview with parents was held taking into account the medical history, assessed by the Myofunctional Orofacial Assessment Protocol $(M B G R)^{10}$. This protocol addresses issues related to pregnancy and birth complications, motor development, motor difficulties, health problems and treatments performed, among others.

The dental evaluation aimed to detect signs suggesting pathological bruxism (non-physiological), as dental wear for example, and verify the presence of the upper first permanent molars and dental flaws. This assessment was conducted by a single dental surgeon.

For the evaluation of BMI status, the subjects had their height and weight measured with a tape attached to the wall and an anthropometric weight scale (Toledo ${ }^{\mathrm{TM}}$ ) respectively. In both procedures, the children were standing barefoot and the approximate weight of their clothes was deducted. The BMI consisted on the ratio between weight (in kilograms) and the square of height (in meters) ${ }^{11}$. Since the sample was composed by children, the parameters adopted were the ones suggested by the World Health Organization ${ }^{12}$. Hence, only eutrophic children, i.e. with BMI status between $5-85 \%$, were included.

The sample comprised 65 children, being 34 girls and 31 boys. They were assigned into groups according to their facial growth pattern, which was determined by the cephalometric evaluation.

The cephalometric evaluation was performed in a radiology and orthodontic imaging center. The procedure consisted on the lateral teleradiography, with a $18 \times 24 \mathrm{~cm}$ film (Kodak ${ }^{\mathrm{TM}}$ ) mounted on chassis coated with Kodak Lanex regular screen and was held in the X-Mind unity ${ }^{\mathrm{TM}}$. This device was equipped with a cephalostat in order to standardize the position of the subject's head in relation to the emitted radiation at a distance of $1.5 \mathrm{~m}$. In the lateral radiography obtained, a computerized cephalometric analysis was held, as well as the Ricketts Analysis.

The VERT index, obtained from the cephalometric analysis, is based on five cephalometric variables (facial axis angle, facial depth, mandibular plane angle, lower height and mandibular arch) and enables the classification of facial types ${ }^{13}$. According to this index, facial types were classified in brachyfacial (VERT index $>0.5$ ); mesofacial (VERT index between -0.5 and +0.5 ); and dolichofacial (VERT index <0.5).

\section{Clinical evaluation of mastication}

The speech-language evaluation was based on the MBGR protocol ${ }^{10}$ and was applied always by the same speech-language pathologist in order to achieve a better standardization and a greater control of the test. Regarding the information presented by this protocol, the following aspects concerning mastication were considered: incision of food; grinding of food; masticatory efficiency; masticatory pattern; labial closure; mastication noise; unexpected muscle twitching and average masticatory time.

The evaluation of chewing performance was carried out with the child sitting with the hip at 90․ Each child was given three portions of French bread and should eat them according to his/her usual habits. The activity was video recorded and independently analyzed by three speech-language pathologists with experience in orofacial motricity. The results should be common for at least two speech-language pathologists in order to be considered. In the situations where there was no agreement between the judges, a new collective analysis was conducted.

\section{Electromyographic evaluation of mastication}

The electromyographic evaluation was performed always by the same speech-language pathologist, avoiding, hence, deviations and differences in the collection procedure. The masseter and anterior temporal muscles were evaluated, in both right and left sides. The subjects were familiarized to the exam procedures, as well as to the local of collection and equipment used. Also, they were trained concerning the collection procedure. They remained seated comfortably with the hip, knees and ankles at 90, oriented by the Frankfurt plane. The muscles were then assessed at rest and at directed continuous chewing.

The rest stage lasted for 10 seconds and aimed to standardize the electrical activity during the baseline condition.

Directed continuous chewing lasted for the tiredness time of the patient and provided the data necessary to achieve our objectives. In accordance to other studies ${ }^{14}$, chewing gum (PlicPloc ${ }^{\mathrm{TM}}$ ) was used, 
since this material well resembles the food, but does not deteriorate or produce any residues, which could affect the evaluation. Initially, subjects were asked to chew the gum for 40 seconds in order to diminish and standardize its hardness. After a rest of 1 minute, children were instructed to chew rhythmically synchronized according to a digital metronome (Cherub - WSM $001 \mathrm{~A}$ ), set at $80 \mathrm{bmp}^{14}$, until they felt tired.

Three collections were performed in both test situations, respecting an interval of 2 minutes of rest for muscle recovery ${ }^{15}$. The analysis selected was always the one presenting better signal quality (analysis by FFT). After choosing the signal, chewing analysis was carried out by excluding the time before the beginning of muscle activity, as well as the first 0.5 seconds of the activity, in order to homogenize the evaluated sections ${ }^{16}$. The following 15 seconds of mastication were selected and analyzed. The electromyographic signal was measured in terms of amplitude (RMS microvolts) and normalized by the maximum peak value.

Regarding the sensors, the international standards where followed ${ }^{17,18}$. Miotec sensors with differential input were placed on the muscle bellies ${ }^{15}$ and connected to DOUBLE type $\mathrm{Ag} / \mathrm{AgCl}$ electrodes (Hal Indústria e Comércio Ltda.) The devices had discotic format (10 $\mathrm{mm}$ diameter). A $20 \mathrm{~mm}$ distance therebetween was kept. Other characteristics were: conductive gel present in a fixed amount; 20X gain; $10 \mathrm{G} \Omega$ input impedance and common mode rejection rate $>100 \mathrm{~dB}$. Also, in order to prevent electromyographic interference, a reference electrode was placed in the patient's glabellar region (connected to the ground).

In order to detect, condition and amplify the electromyographic signal, the Miotool equipment (Miotec) was used with 8 input channels, 14 bit $A / D$ converter in the electromyographic signal acquisition channels, $5000 \mathrm{~V}$ electrical isolation, data acquisition capability of 2000 samples/second/channel, $20 \mathrm{~Hz}$ high-pass and $500 \mathrm{~Hz}$ low-pass filter. The collection and signal processing were performed by Miograph 2.0 software and saved in a HP Pavilion dv5-204br laptop with 500 GB HD and 4 GB of RAM, with no connection to the power grid.

The skin was previously cleaned with a $70 \%$ ethanol solution and gauze in order to diminish its impedance. The physical location where the collections were performed, including both the equipment and the chair evaluation area, was carefully treated: the floor was covered in rubberized Paviflex. Moreover, all equipment that would electromagnetically interfere with the exam was turned off and kept at a safe distance ${ }^{15}$.

\section{Statistical Analysis}

After tabulating the data, statistical analysis was performed using the Statistical Analysis System (SAS), version 9.2. Chi-square and Fisher's exact tests were used to compare categorical variables of clinical evaluation, being the latter applied when expected values were lower than 5. To compare numerical variables, non-parametric tests were used due to the absence of a normal distribution, indicated by the Shapiro-Wilk test.

The Kruskal-Wallis test was used to compare the numerical variables of clinical and electromyographic evaluations among the three groups. The Friedman test was used for comparison between muscles in the electromyographic evaluation within each facial type. In all tests, the level of significance was set at $5 \%$ $(p<0.05)$.

\section{RESULTS}

Table 1 shows the frequency distribution concerning the gender, age and facial type of the studied group. A similar distribution between genders and ages was observed. Regarding the facial pattern, on the other hand, more than half of the children evaluated were considered brachyfacial (63.08\%).

The relationship between facial types and clinical evaluation of chewing performance is shown in Table 2. There was no significant difference among the three groups assessed. However, a tendency to significance in respect to muscle contractions not usually expected during mastication was observed. This trend was most marked in dolichofacial (66.67\%), followed by mesofacial (46.67\%).

The results of the electromyographic evaluation of mastication associated to facial patterns are presented in Table 3. While the analysis shows there are no significant differences between the three groups, the electrical activity of the muscles evaluated in brachyfacial children did differ. A higher electrical activity was detected on the right masseter muscle when compared to the left one. Also, higher electrical activity was found on the left temporal muscle in comparison to the right one. 
Table 1. Characterization of the subjects ( $n=65$ children)

\begin{tabular}{cccc}
\hline & & Frequency & Percentage \\
& & $(\mathbf{n})$ & 52.31 \\
Gender & Female & 34 & 47.69 \\
& Male & 31 & 29.23 \\
\hline \multirow{2}{*}{ Age group } & $6-7$ years & 19 & 38.46 \\
& $8-9$ years & 25 & 32.31 \\
\hline \multirow{2}{*}{ Type of face } & $10-12$ years & 21 & 63.08 \\
& Brachyfacial & 41 & 23.08 \\
& Mesofacial & 15 & 13.85 \\
\hline
\end{tabular}

Key: $n$ - number of children; \% - percentage.

Table 2. Clinical evaluation of mastication and type of face of the subjects

\begin{tabular}{|c|c|c|c|c|}
\hline \multirow[b]{2}{*}{ Clinical evaluation of mastication } & \multicolumn{3}{|c|}{ Type of face } & \\
\hline & $\begin{array}{c}\text { Brachyfacial } \\
n=41\end{array}$ & $\begin{array}{c}\text { Mesofacial } \\
n=15\end{array}$ & $\begin{array}{c}\text { Dolichofacial } \\
n=9\end{array}$ & \\
\hline Incision of food & $n(\%)$ & $\mathrm{n}(\%)$ & $\mathrm{n}(\%)$ & \multirow[t]{3}{*}{$p^{*}=1.000$} \\
\hline Anterior & $36(90.00)$ & $14(93.33)$ & $9(100.00)$ & \\
\hline Lateral & $0(10.00)$ & $1(6.67)$ & $4(0.00)$ & \\
\hline Grinding of food & $\mathrm{n}(\%)$ & $\mathrm{n}(\%)$ & $\mathrm{n}(\%)$ & \multirow[t]{4}{*}{$p^{*}=0.139$} \\
\hline Posterior teeth & $38(92.68)$ & $11(73.33)$ & $8(88.89)$ & \\
\hline Anterior teeth & $3(7.32)$ & $4(26.67)$ & $1(11.11)$ & \\
\hline By the tongue & $0(0.00)$ & $0(0.00)$ & $0(0.00)$ & \\
\hline Grinding efficiency & $\mathrm{n}(\%)$ & $\mathrm{n}(\%)$ & $\mathrm{n}(\%)$ & \multirow[t]{3}{*}{$p^{*}=0.366$} \\
\hline Efficient & 38 (92.68) & $14(93.33)$ & $7(77.78)$ & \\
\hline Inefficient & $3(7.32)$ & $1(6.67)$ & $2(22.22)$ & \\
\hline Masticatory pattern & $\mathrm{n}(\%)$ & $\mathrm{n}(\%)$ & $\mathrm{n}(\%)$ & \multirow[t]{5}{*}{$p^{*}=0.729$} \\
\hline Bilateral alternating & $10(25.00)$ & $6(40.00)$ & $3(33.33)$ & \\
\hline Unilateral preferred & $25(62.50)$ & $8(53.33)$ & $4(44.44)$ & \\
\hline Bilateral simultaneous & $2(5.00)$ & $0(0.00)$ & $1(11.11)$ & \\
\hline Unilateral chronic & $3(7.50)$ & $1(6.67)$ & $1(11.11)$ & \\
\hline Labial closure & $\mathrm{n}(\%)$ & $\mathrm{n}(\%)$ & $\mathrm{n}(\%)$ & \multirow[t]{4}{*}{$p^{*}=0.344$} \\
\hline Systematics & $29(70.73)$ & $9(60.00)$ & $4(44.44)$ & \\
\hline Non-systematic & $11(26.83)$ & $5(33.33)$ & $4(44.44)$ & \\
\hline Absent & $1(2.44)$ & $1(6.67)$ & $1(11.11)$ & \\
\hline Mastication noises & $\mathrm{n}(\%)$ & $\mathrm{n}(\%)$ & $\mathrm{n}(\%)$ & \multirow[t]{3}{*}{$p^{\star}=0.606$} \\
\hline No & $40(97.56)$ & 14 (93.33) & $9(100.00)$ & \\
\hline Yes & $1(2.44)$ & $1(6.67)$ & $0(0.00)$ & \\
\hline Unexpected muscular twitching & $\mathrm{n}(\%)$ & $\mathrm{n}(\%)$ & $\mathrm{n}(\%)$ & \multirow[t]{3}{*}{$p^{\star \star}=0.054$} \\
\hline Absent & $30(73.17)$ & $8(53.33)$ & $3(33.33)$ & \\
\hline Present & $11(26.83)$ & $7(46.67)$ & $6(66.67)$ & \\
\hline \multirow{2}{*}{ Average masticatory time } & média $\pm \mathrm{DP}$ & média $\pm \mathrm{DP}$ & média $\pm \mathrm{DP}$ & \multirow{2}{*}{$p^{\star \star *}=0.369$} \\
\hline & $18.55 \pm 7.59$ & $18.58 \pm 6.40$ & $22.64 \pm 8.68$ & \\
\hline
\end{tabular}

Key: $n$ - number of children; \% - percentage; SD - Standard deviation; * Fisher's exact test ; ** Chi-Squared test; ***Kruskal-Wallis test. 
Table 3. Electromyographic evaluation of mastication and type of face of the subjects

\begin{tabular}{|c|c|c|c|c|}
\hline \multirow{3}{*}{ Electromyographic evaluation of mastication } & \multicolumn{3}{|c|}{ Type of face } & \multirow{3}{*}{$p^{* *}$} \\
\hline & $\begin{array}{c}\text { Brachyfacial } \\
n=41\end{array}$ & $\begin{array}{c}\text { Mesofacial } \\
n=15\end{array}$ & $\begin{array}{c}\text { Dolichofacial } \\
n=9\end{array}$ & \\
\hline & average $\pm S D$ & average $\pm S D$ & average $\pm S D$ & \\
\hline Right masseter (RM) & $14.14 \pm 3.41$ & $15.37 \pm 3.19$ & $13.61 \pm 3.23$ & 0.378 \\
\hline Right temporal (RT) & $13.20 \pm 3.03$ & $13.78 \pm 3.10$ & $12.78 \pm 2.03$ & 0.615 \\
\hline Left masseter (LM) & $13.88 \pm 3.19$ & $15.01 \pm 4.27$ & $12.97 \pm 2.76$ & 0.359 \\
\hline Left temporal (LT) & $14.41 \pm 3.07$ & $14.87 \pm 2.88$ & $13.40 \pm 2.51$ & 0.464 \\
\hline \multirow{3}{*}{$\begin{array}{l}p^{\star * *} \text { comparison between muscles evaluated in } \\
\text { each type of face. }\end{array}$} & $0.049^{*}$ & \multirow{3}{*}{0.575} & \multirow{3}{*}{0.589} & \\
\hline & $\mathrm{TD} \neq \mathrm{MD}$ & & & \\
\hline & $\mathrm{TD} \neq \mathrm{TE}$ & & & \\
\hline
\end{tabular}

Key: $n$ - number of children; SD- Standard deviation; *Friedman test $\mathrm{p}<0.05$; ${ }^{* \star}$ Kruskal-Wallis' test; ${ }^{* \star \star}$ Friedman test.

\section{DISCUSSION}

The aim of this study was to analyze the relationship between chewing and facial patterns, regardless of gender and age. Another study showed no statistically significant differences between chewing performance on boys and girls in the intertransitional period during mixed dentition period ${ }^{19}$.

The age group considered is the same as from other studies in literature ${ }^{20,21}$ which consisted of children aged between 6-12 years who presented erupted first permanent molars.

The choice of the age group is justified by the fact that at an age of approximately 6 , transformations occur in the oral cavity as a result of the first permanent molars eruption. At 12, the second permanent molars erupt ${ }^{20}$, which is an important condition for occlusal stability, as well as for electromyographic signal stability.

Regarding the facial growth pattern, it was verified a higher incidence percentage of brachyfacial, followed by mesofacial and dolichofacial respectively (Table 1). These results were not expected, since most studies report a greater incidence of mesofacial type ${ }^{22,23}$.

The higher frequency of brachyfacial compared to other facial types may be justified by the characteristics of the region where the study was conducted. The significant ethnic mix present in this region reinforces the importance of genetic factors in the establishment of the facial patterns ${ }^{5}$.

There was no statistically significant difference in most of the variables studied on the clinical evaluation of chewing performance when comparing different facial patterns. However, there was a trend towards significance on the aspect "unexpected muscle twitching", which was more marked in dolichofacial, followed by mesofacial subjects (Table 2). According to the literature, dolichofacial subjects may present such contractions, as well as inefficient grinding of food, which might be related to the hypofunctional masticatory muscles ${ }^{24}$. This inefficiency was also reported by other authors ${ }^{25}$ who associated it to a smaller occlusal contact area. There was also no statistically significant difference amongst the three types of face regarding other variables assessed by the evaluation, such as incision of food, masticatory efficiency, mastication noise and lip closure (Table 2).

These results anticipate that other variables not considered in this study, such as mixed dentition period, severe open-bite, presence of dental flaws, poor dental state, malocclusion, temporomandibular disorders and bruxism may be related to changes in clinical characteristics of mastication and not to the facial type ${ }^{26-29}$.

The results found in the electromyographic evaluation of this study reinforce our findings of the clinical evaluation, i.e. the greater need of muscle contraction during chewing on dolichofacial individuals. Although there was no significant difference between groups, dolichofacial children presented lower average electrical activity in all muscles assessed (Table 3 ).

Despite having methodologies based on mandibular rest and isometric conditions, other studies corroborate our results, showing lower electrical activity values in masseter muscles in this group ${ }^{25,30-32}$.

On the other hand, another study detected differences in the electrical activity of maximum voluntary contraction and relaxation of the masseter and temporal muscles in all three patterns of vertical growth. The electrical activity distribution followed the same pattern evidenced by the aforementioned studies, being higher in brachyfacial and lower in dolichofacial subjects. The authors then concluded that the craniofacial 
morphology affected the electrical activity of the masticatory muscles studied ${ }^{25}$.

When comparing the electrical activity of the muscles evaluated in each facial pattern group, a statistically significant difference $(p=0.049 *)$ was verified only for the brachyfacial group. This highlights the higher activity of the right masseter muscle in relation to the left one and the opposite situation for the temporal muscle, i.e. higher activity on the left side $(p=0.049)$.

As reported in literature, brachyfacial individuals show a greater thickness of the masseter muscle, a wider nasal airway and a lower third of the lower face. Meso and dolichofacial individuals, on the other hand, present thinner masseter and shorter endurance time $^{24,33}$. Therefore, the higher activity of the masseter in comparison to the temporal muscle in this group may have been affected by this morphophysiological feature.

These results are in disagreement with another study ${ }^{34}$, which evaluated the activity of the masticatory muscles of children throughout a day of activity, excluding feeding and sleeping time. The authors observed that the temporal muscle showed a greater activity than the masseter, regardless of the facial growth pattern.

Also, the electrical activities of the left and right temporal muscles for brachyfacial group are different, as indicated by our results.

Studies state that brachyfacial individuals may present oral pathologies, such as bruxism and temporomandibular disorders ${ }^{26}$. These characteristics, which were not investigated in this study, together with the unilateral chewing side preference may have influenced the asymmetry observed in the electromyographic evaluation.

Once this subject enables the awareness of the particularities of the masticatory function in different types of face and given its importance for clinical practice, further investigations with more balanced samples regarding groups constitution are suggested. Also, some not yet considered variables that might interfere with the chewing performance of individuals with different facial growth pattern should be included, as suggested by other authors ${ }^{32}$.

\section{CONCLUSION}

According to the results obtained in this study, it is possible to infer that:

Clinical and electromyographic evaluations did not indicate any difference between different facial patterns. This suggests that the facial growth pattern by itself is not determinant in modifications of the masticatory function, which therefore may be related to other variables not considered in this study.

There was a tendency to unexpected muscular twitching in mastication, mainly in dolichofacial children followed by mesofacial.

Brachyfacial children presented higher electrical activity of the right masseter when compared to the left one and higher electrical activity of the left temporal when compared to the right one.

\section{REFERENCES}

1. Rizzo MC, Akaishi NMM, Naspitz N. Multidisciplinary aspects of oral breathing in children Allergie Suppl. 2001;1(2):59-60.

2. Berwig LC, Silva AMT, Côrrea ECR, Moraes AB, Montenegro MM, Ritzel RA. Análise quantitativa do palato duro em diferentes tipologias faciais de respiradores nasais e orais. Rev CEFAC. 2012;14(4):616-25.

3. Bolzan GP, Berwig LC, Prade LS, Weinmann ARM, Moraes $A B$, Silva AM. Concordância entre método antropométrico e cefalométrico na classificação do tipo facial. Rev CEFAC. 2014;16(1):222-7.

4. Bianchini EMG. Avaliação fonoaudiológica da motricidade oral - distúrbios miofuncionais orofaciais ou situações adaptativas. Rev Dental Press OrtodonOrtop Facial. 2001;6(3):73-82.

5. Busanello-Stella AR. Fadiga Muscular: Análise dos Músculos Orbiculares da Boca e Mastigatórios de Crianças de 6 A 12 anos de idade [tese]. Santa Maria (RS): Universidade Federal de Santa Maria; 2014.

6. Rahal A, Goffi-Gome MVS. Estudo eletromiográfico do músculo masseter durante o apertamento dentário e mastigação habitual em adultos com oclusão dentária normal. Rev Soc Bras Fonoaudiol. 2009;14(2):160-4.

7. Rahal A, Goffi-Gomez MVS. Avaliação eletromiográfica do músculo masseter em pessoas com paralisia facial periférica de longa duração. Rev CEFAC. 2007;9(2):207-12.

8. Pizzol KE. Influência da Mastigação Unilateral no desenvolvimento da Assimetria Facial. Rev UNIARA. 2004;15:215-9

9. Mangilli LD, Sassi FC, Sernik RA, Tanaka C. Caracterização eletromiográfica e ultrassonográfica da função mastigatória em indivíduos com oclusão normal. J Soc Bras Fonoaudiol. 2012;24(3):211-7. 
10. Genaro KF, Berretin-Felix G, Rehder MIBC, Marchesan IQ. Avaliação miofuncional orofacial protocolo MBGR. Rev CEFAC. 2009;11(2):237-55.

11. Rosner B, Prineas R, Loggie J, Daniels SR. Percentiles for body mass index in U.S. children 5 to 17 years of age. J Pediatrics. 1998;132(2):211-22.

12. Organização Mundial da Saúde. Padrões de Crescimento Infantil. 2006. Disponível em: </http: www.saude.org.br/>. Acesso em: 30 abril. 2014.

13. Ricketts RM. Orthodontic diagnosis and planning their roles in preventive and rehabilitative dentristy. Denver: Rocky Mountain Orthodontics. 1982;1:269.

14. Mendonça RG, Oliveira AS, Pedroni CR, Bérzin F, Gastaldi AC. Electromyography assessment of chewing induced fatigue in temporomandibular disorders patients. Braz J Oral Sci. 2005;4(15):894-8.

15. De Luca C.J. The use of surface electromyography in biomechamics. Journal of applied biomechanics. 1997;13(2):135-63.

16. Silva SRD, Gonçalves M. Comparação de protocolos para verificação da Fadiga Muscular pela Eletromiografia de Superfície. Motriz. 2003;9(1):51-8.

17. Merletti R. Standards for Reporting EMG data. Journal of Electromyography and Kinesiology. 1999;1:3-4.

18. Hermens HJ, Freriks B, Disselhorst-Klug C, Rau G. Development of recommendations for SEMG sensors and sensor placement procedures. Journal of electromyography and kinesiology. 2000;10(5):361-74.

19. Motta AR. Descrição da mastigação no período intertransicional da dentição mista. [mestrado]. São Paulo (SP): Pontifícia Universidade Católica de São Paulo. 2002:32-7.

20. Cattoni DM, Fernandes FDM, Marchesan IQ, Latorre MRDO. Medidas antropométricas faciais em crianças segundo períodos da dentição mista. Rev CEFAC. 2003;(5):21-9.

21. Bolzan GP, Silva AMT, Boton LM, Corrêa ECR. Estudo das medidas antropométricas e das proporções orofaciais em crianças respiradoras nasais e orais de diferentes etiologias. Rev. soc. bras. fonoaudiol. 2011;16(1):85-91.

22. Silva Filho OG, Herkrath FJ, Queiroz APC, Aiello CA. Padrão facial na dentadura decídua: estudo epidemiológico. R Dental Press Ortodon Ortop Facial. 2008;4(13):45-59.

23. Paranhos LR, Magalhães MPM, Bérzin F, Daruge Júnior E, Torres FC. Prevalência do padrão esquelético facial em indivíduos com oclusão normal natural. Ortodontia. 2010;43(3):237-42.

24. Ramires RR, Ferreira IP, Marchesan IQ, Cattoni DM, Silva MAA. Tipologia facial aplicada à Fonoaudiologia: revisão de literatura. Rev Soc Bras Fonoaudiol. 2010;15(1):140-5.

25. Farias Gomes SG, Custodio W, Jufer JSM, Cury AADB, Cunha R, Garcia MR. Mastication, EMG Activity and Occlusal Contact Areain Subjects with Different Facial Types. The journal of craniomandibular practice. 2010;4(28):274-9.

26. Busanello-Stella AR, Berwig LC, Almeida FL, Silva AMT, Mello FM. Aspectos do sistema estomatognático de indivíduos bruxistas. Salusvita. 2011;1(30):7-20.

27. Andrada e Silva Ma, Natalini V, Ramires RR, Ferreira LP. Análise comparativa da mastigação de crianças respiradoras nasais e orais com dentição decídua. Rev CEFAC. 2007;1(9):190-8.

28. Weber P, Corrêa ECR, Bolzan GP, Ferreira FDS, Soares JC, Silva AMT. Mastigação e deglutição em mulheres jovens com desordem temporomandibular. Codas. 2013;1(25):375-80.

29. Pastana SG, Costa SM, Chiappetta ALML. Análise da mastigação em indivíduos que apresentam mordida cruzada unilateral na faixa-etária de 07 a 12 anos. Rev CEFAC. 2007;3(9):339-50.

30. Rodrigues KA, Rahal A. A influência da tipologia facial na atividade eletromiográfica do músculo masseter durante o apertamento dental em máxima intercuspidação. Rev. CEFAC. 2003;2(5):127-30.

31. Farella M, Michelotti A, Carbone G, Gallo LM, Palla S, Martina R. Habitual daily masseter activity of subjects with different vertical craniofacial morphology. Eur J Oral Sci. 2005;113(5):380-5.

32. Vianna-Lara M.S, Caria PHF, Tosello DO, Lara F, Amorim MM. Electromyographic activity of masseter and temporal muscles with different facial types. Angle Orthod. 2009;3(79):515-20.

33. Lione R, Franchi L, Noviello A, Bollero P, Fanucci E, Cozza P. Three-Dimensional Evaluation of Masseter Muscle in Different Vertical Facial Patterns: A CrossSectional Study in Growing Children. Ultrasonic Imaging. 2013;35(4):307-17.

34. Ueda HM, Miyamoto K, Saifuddin MD, Ishizuka Y, Tanne K. Masticatory muscle activity in children and adults with different facial type. American Journal of Orthodontics and Dentofacial Orthopedics. 2000;1(118):63-8. 